\title{
Electric Power Resource "Shuffling" and Subnational Carbon Regulation: Looking Upstream for a Solution
}

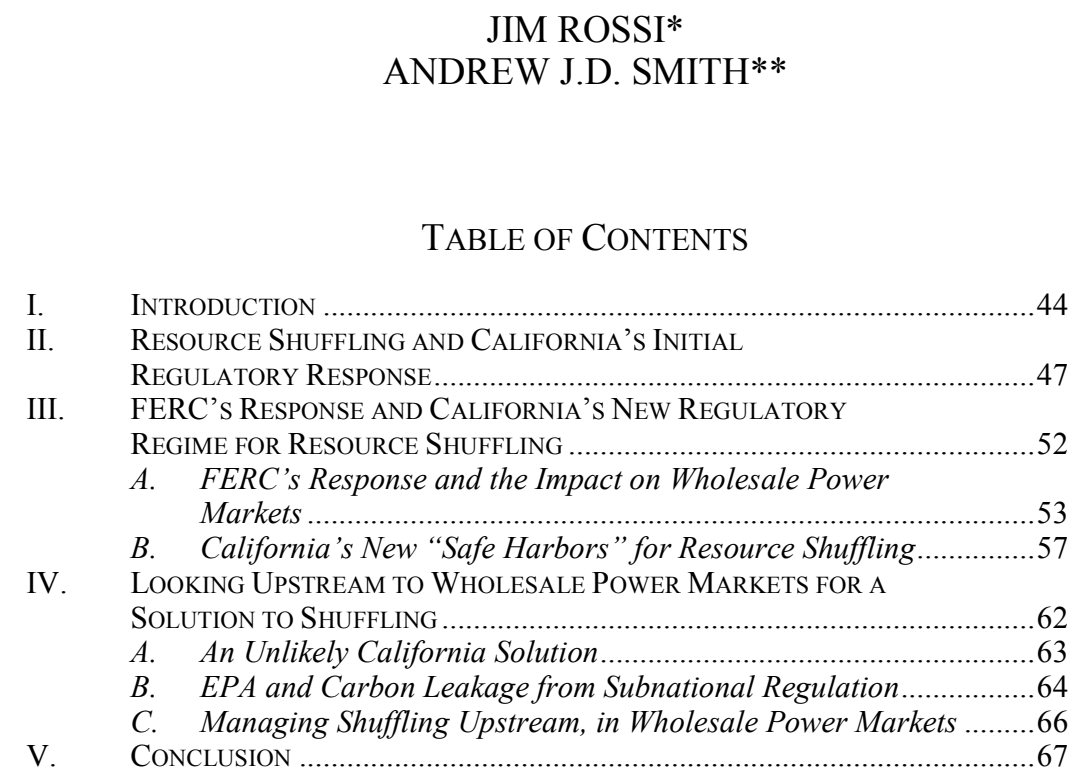

* $\quad$ (C) 2014 Jim Rossi. Professor, Vanderbilt University Law School. LL.M., Yale Law School; J.D., University of Iowa College of Law; B.S., Arizona State University.

** (C) 2014 Andrew J.D. Smith. J.D. 2014, Vanderbilt University Law School; B.A. 2010, Brown University. 


\section{INTRODUCTION}

"Resource shuffling" occurs when different subnational approaches to carbon regulation create variations in the costs of production across jurisdictions. California is the most aggressive jurisdiction in the United States to address climate change and has adopted a cap \& trade program for its greenhouse gas (GHG) emissions. This Article addresses the resource shuffling issue presented by California's cap-and-trade program and evaluates the merits of various legal and regulatory solutions to the problem.

Opportunities for resource shuffling arise because of the competitive interstate electric power market, which is managed largely by the Federal Energy Regulatory Commission (FERC). Left to market forces, utilities seeking to purchase electricity generally favor the least-cost source of electric power. Federally managed interstate markets tend to reinforce these least-cost power dispatch practices (i.e., transmission operators deploy resources to meet demand based on the least marginal cost), but this poses a potential challenge for subnational regulation of carbon emissions, such as California's cap-and-trade program.

A primary goal of California's program is to force power generation facilities within its borders to reduce carbon dioxide emissions while allowing individual producers and sellers of energy to make their own choices regarding resource allocation. However, California's cap-and-trade scheme seeks to do more than reduce greenhouse gas emissions that occur from plants within state borders; it also seeks to reduce all emissions that occur as a result of electricity consumed within California's borders, regardless of where the power supply source is located. ${ }^{1}$

The potential for resource shuffling-replacing cleaner sources of electric power with dirtier and cheaper sources of energy-threatens to undermine California's environmental goals. About 30 percent of the electricity consumed in California is imported from other states. ${ }^{2}$ This imported electricity tends to come from disproportionately dirty sources (such as coal) and represents more than half of the carbon dioxide emitted as a result of the state's electricity demand. ${ }^{3}$ Because of the significance of these out-of-state GHG emissions, California's cap-and-trade regime would only address a small portion of the actual GHG impacts associated

1. See CAl. Code Regs. Tit. 17, § 95802(a)(140), 95811(b).

2. California Electricity Statistics \& Data, ENERGY AlmANAC, http://energyalmanac. ca.gov/electricity/ (last visited Mar. 3, 2014).

3. James Bushnell, The Implementation of California AB 32 and its Impact on Wholesale Electricity Markets, CENTER FOR THE STUDY OF ENERGY MARKETS at 5, August 2007, available at http://www.iern.net/portal/page/portal/IERN_HOME/IERN_ARCHIV/ Publications/Competition_Issues/57AA9CE3EC9140C1E040A $\overline{8}$ C03C2F75CB. 
with energy consumption within the state-absent some mechanism to reduce or eliminate incentives power sellers have to import energy from dirtier sources of electric power.

As a matter of economic policy a state like California has an additional incentive to eliminate resource shuffling. Resource shuffling exacerbates the problem of industrial-relocation carbon leakage because it leads to a situation in which covered entities are subject to emission limits and corresponding carbon price premiums, but out-of-state producers that export their power into the state are allowed to evade these limits and premiums. Thus, without some means of controlling resource shuffling, out-of-state producers and importers of power stand to benefit at the expense of instate electric power generators. Overly aggressive efforts by California regulators to address this problem can also raise issues of protectionism that run afoul of the Dormant Commerce Clause. ${ }^{4}$ The extent to which California has authority to regulate or even consider GHG emissions that occur outside of its borders under the Commerce Clause of the U.S. Constitution is subject to some dispute ${ }^{5}$ - although recent case law would seem to favor California's efforts to regulate emissions from out-of-state sources. $^{6}$

California regulators operate under a statutory obligation to minimize the leakage associated with the state's GHG emissions programs, so reducing or eliminating shuffling appears to be required under state law. ${ }^{7}$ California regulators have sought to prohibit resource shuffling, but the state's approach to addressing resource shuffling has presented a potential tension with federal regulation of wholesale electric power markets, leading the state to suspend enforcement of its shuffling prohibitions and to

4. As its name implies, the so-called "Dormant" Commerce clause does not expressly appear in the Constitution, but is derived from the Commerce Clause. See U.S. ConsT. art. I, $\S 8$, cl. 3 .

5. For a defense of the constitutionality of California's anti-resource-shuffling regulations under the Dormant Commerce Clause, see ERIN PARLAR, MichaEl BABAKITIS \& Shelley Welton, Legal Issues in Regulating Imports in State and Regional CaP AND TRADE PROGRAMS 17-46 (2012), available at http://web.law.columbia.edu/sites/default/ files/microsites/climate-change/files/Publications/Students/Legal\%20Issues\%20in\%20Reg ulating\%20Imports\%20OCT2012.pdf [hereinafter Parlar].

6. See Rocky Mountain Farmer's Union v. Corey (9th Cir. 2013), No. 12-15131 (upholding California's fuel standards under the Commerce Clause, even though they have an extraterritorial impact on out-of-state producers importing fuel into California).

7. Cal. Health \& Safety Code $§ 38562(b)(8)$ (West 2013). 
reassess its regulatory approach to the problem. ${ }^{8}$ Despite these changes, California's modified approach to regulating resource shuffling remains problematic for the operation of wholesale power markets. This Article argues that short of a federal cap-and-trade program or a carbon tax that has a preemptive legal effect on state GHG regulation, federal regulators must play some role to minimize the tension between wholesale power markets and resource shuffling by paying attention to upstream interstate markets in electric power. Such an approach can encourage subnational innovation in GHG regulation without thwarting the efficiency or reliability of wholesale power markets.

Part II of this Article describes resource shuffling and its significance for subnational efforts to regulate GHG emissions, such as California's cap-and-trade program for carbon emissions. It also discusses California's initial regulatory response to resource shuffling, known as "attestation." Part III discusses the tension that California's initial regulatory strategy presented with federal regulators who oversee wholesale electric power markets. California's amended "safe harbor" approach to regulating shuffling fails to avoid this tension and may even increase uncertainty for wholesale power markets.

Part IV evaluates ways to more effectively regulate resource shuffling. One way California can address shuffling is to adjust the cap or emissions limits to reflect that shuffling would occur. Ultimately, however, this Article argues that since shuffling is a form of carbon leakage a federal approach to addressing shuffling will be superior to subnational efforts. The conventional federal solution to leakage is to look to emissions regulation by the EPA to harmonize regulatory differences across states. This Article argues that while this conventional approach can potentially address a significant portion of the problem associated with resource shuffling, it is imperfect given the EPA's anticipated flexible approach to carbon regulation. Federal energy regulators could improve the efficacy of subnational efforts to address GHG emissions and produce greater certainty for power markets by addressing resource shuffling through a

8. See Letter from Philip D. Moeller, Commissioner, FERC, to the Honorable Edmund G. Brown, Governor of California (Aug. 6, 2012), available at http://www.ferc. gov/about/com-mem/moeller/moeller-08-06-12.pdf [hereinafter Letter from Moeller]; Letter from Mary D. Nichols, Chairman, California Air Resource Board, to Philip D. Moeller, Commissioner, Federal Energy Regulatory Commission (Aug. 16, 2012), available at http:// www.arb.ca.gov/newsrel/images/2012/response.pdf [hereinafter Letter from Nichols]; CAL. Air Res. BD, Resolution 12-33, CALIFORNIA CAP-AND-TRADE Program (2012), available at http://www.arb.ca.gov/cc/capandtrade/res12-33.pdf [hereinafter Resolution 12-33]; CAL. AIR RES. BD, Resolution 12-51, CAL. CAP-AND-TRAde Program (2012), available at http://www.arb.ca/gov/cc/capandtrade/final-resolution-october-2012.pdf [hereinafter Resolution $12-51]$. 
harmonized set of rules or guidelines articulating acceptable least-cost dispatch protocols for the operation of wholesale power markets. Until that occurs, resource shuffling will continue to occur, thwarting the ability of subnational regulation to achieve GHG-reduction goals, and uncertainty about shuffling will continue to plague interstate power markets.

\section{RESOURCE SHUFFLING AND CALIFORNIA's INITIAL REGULATORY RESPONSE}

To address the problem of global climate change, California has adopted a number of policies, including a Renewable Portfolio Standard (RPS), ${ }^{9}$ a Low Carbon Fuel Standard (LCFS), ${ }^{10}$ and a GHG cap-and-trade program. ${ }^{11}$ Each of these policies is susceptible to carbon leakage, but California's cap-and-trade program and its application to the electric power industry is the focus of this Article. Recognizing both the importance of electricity generation as a source of GHG emissions and the sizeable share of power imports, California has crafted its cap-and-trade program to reduce not only the GHG emissions created within state borders but also all emissions generated as a result of electricity consumed within the state. ${ }^{12}$

In large part, this expansion in the scope of the state's GHG policy stems from a desire to minimize the impacts of carbon leakage. The potential for carbon leakage occurs where one jurisdiction creates carbondioxide-emissions regulations that are more stringent than neighboring jurisdictions. These more restrictive regulations increase the price of industrial activity - and thus the price of goods and services - in the first jurisdiction, creating a competitive advantage for the less restrictive jurisdictions. This competitive advantage can lead neighboring jurisdictions to increase their output and accompanying GHG emissions, thus negating any potential benefits of the original jurisdiction's GHG-emission restrictions.

Even if power plants do not relocate to other jurisdictions, California's broad approach to addressing GHG emissions makes power markets vulnerable to a form of gaming called "resource shuffling." In other words, buyers and sellers of electricity in the interstate market can take advantage

9. Cal. Pub. Util. Code $\S 399.16$, et seq. (2013).

10. CAL. CODE REGS. tit. 17, §§ 95480-90 (2013).

11. CAL. Code Regs. tit. 17, §§ 95801, et seq. (2013).

12. CAL. Code Regs. tit. 17, §§ 95802(a)(140), 95811(b) (2013). 
of differences in costs across jurisdictions to by structuring their transactions to claim credit under the cap-and-trade program for GHGemissions reductions that only take place on paper.

At the outset, an illustration of shuffling might help demonstrate its significance as a problem, as well as California's response to it. Suppose that two power plants with equal production capacity are both located outside of California's borders. Plant A burns high-carbon coal, while Plant B uses relatively low-carbon natural gas. For years, Plant A has operated under a contract to sell power to a California utility (for delivery to customers within California's borders), while Plant B has a contract to sell power to a Nevada utility. Since the California utility must buy permits for its GHG emissions, Plant A becomes more expensive. Shuffling occurs when the Californian utility swaps contracts with the NV utility, thus lowering its compliance costs. Both plants continue operating and producing the same amount of electric power. In this example there is no overall emissions reduction, but if Plant $\mathrm{A}$ is located further from the Nevada utility than Plant B, the Nevada utility may need to purchase a greater amount of electric power from Plant A to cover the line losses associated with transmission, and there could actually be an increase in the overall GHG emissions associated with delivering the same amount of electricity to customers.

California directly responded to the problem of shuffling by prohibiting it in its initial regulations implementing its GHG cap-and-trade program. California Health \& Safety Code $\S 38562$ (b)(8) requires that the California Air Resources Board (ARB) design its cap-and-trade rules in such a way that they minimize leakage. ARB has chosen to minimize leakage through a "first-deliverer" approach. ${ }^{13}$ Under the first-deliverer approach, California's cap-and-trade regulations apply to all first deliverers of electricity into the California grid, which includes both electricity-generating facilities in California and "electricity importers." 14 ARB has defined electricty importers as follows:

"Electricity importers" deliver imported electricity. For electricity that is scheduled
with a [North American Electric Reliability Corporation (NERC)] e-Tag to a final
point of delivery inside the state of California, the electricity importer is identified
on the NERC e-Tag as the purchasing- selling entity (PSE) on the last segment of
the tag's physical path with the point of receipt located outside the state of
California and the point of delivery located inside the state of California. For facilities
physically located outside the state of California with the first point of
interconnection to a California balancing authority's transmission and distribution
system when the electricity is not scheduled on a NERC e-Tag, the importer is the

13. See CAL. Code Regs. tit. 17, §95811 (2013). For a discussion of alternative approaches, see PARLAR, supra note 5, at 9-17.

14. Id. 
facility operator or scheduling coordinator. Federal and state agencies are subject to the regulatory authority of ARB under this article and include Western Area Power Administration (WAPA), Bonneville Power Administration (BPA), and California Department of Water Resources (DWR). 15

By subjecting electricity importers to the reporting and compliance obligations, ARB's cap-and-trade rules aim to reduce not only domestic emissions but also out-of-state emissions that occur as a consequence of meeting California's electricity demand. ${ }^{16}$

CARB's first-deliverer approach to reducing out-of-state emissions that result from Californian electricity demand is vulnerable to a particular form of gaming called "resource shuffling." ARB has identified three specific forms of resource shuffling: 1) laundering, 2) cherry picking, and 3) facility swapping. ${ }^{17}$

Laundering is made possible by ARB's provision for "unspecified power." When electricity is purchased from the grid, the original generation source is not always specified. ${ }^{18}$ As a practical measure, ARB's cap-andtrade regulations assign unspecified power a "default emissions rate," which an electricity importer uses to calculate its reporting and compliance obligations. $^{19}$ The level at which this default emissions rate is set is important: if the rate is set higher than the actual emissions rate, then electricity importers will have an incentive to specify the source of their power in order to report fewer emissions and use up fewer allowances; if the default rate is set lower than actual emissions, the electricity importers will have an incentive to avoid specified power because using the default

15. CAL. CODE Regs. tit. 17, § 95802(a)(140) (2013). For a helpful visual description of the electricity importer concept, see SCOTT MURTISHAW, FIRST DELIVERER Approach to Regulating Electricity Imports in CAP AND Trade Programs 7, 14

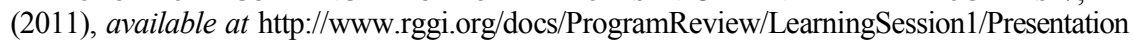
_Scott_Murtishaw_CA_PUC.pdf.

16. In addition, the fact that ARB relies on NERC e-Tags to identify electricity importers is significant because it potentially exacerbates the potential for California to engage in extraterritorial regulation of the electricity industry, as evidenced by a recent California Independent System Operator (CAISO) tariff dispute heard by the Federal Energy Regulatory Commission (FERC). See generally, Order Accepting Compliance Filing, Denying Late Interventions, and Dismissing Rehearing Requests, 142 FERC

61,111, Docket Nos. ER12-1856-001, ER12-1856-002, Issued Feb. 13, 2013. However, a full treatment of this issue is beyond the scope of this article.

17. Cal. Air Res. Bd., CaP-And-Trade Program Electricity Workshop 24 (2012), http://www.arb.ca.gov/cc/capandtrade/meetings/050412/may4electricityppt.pdf.

18. See CAL. Code Regs. tit. 17, § 95802(a)(281) (2013).

19. See Cal. Code Regs. tit. 17, §§ 95111(b)(1), 95852(b)(1)(B) (2013). 
emissions rate will lower their reporting and compliance obligations. ${ }^{20}$ Laundering is the phenomenon that occurs in the latter situation. Sources have described laundering as electricity importers labeling electricity whose source is or could be specified as unspecified in order to take advantage of the comparatively lower default emissions rate, ${ }^{21}$ though electricity importers could achieve this same result by terminating their contracts with high-emission, specified sources of power and replacing those contracts with unspecified power. ARB has set the default emissions rate at $.428 \mathrm{MT}$ of $\mathrm{CO}_{2} \mathrm{e} / \mathrm{MWh}$, which is representative of a relatively cleanburning natural gas plant. ${ }^{22}$ Because this emissions rate is relatively low, there is a significant possibility for extensive resource laundering. ${ }^{23}$ One study estimates that labeling all specified power as unspecified would result in an on-paper reduction of $10 \mathrm{~mm}$ tons of carbon dioxide that would not occur in the real world. ${ }^{24}$

Cherry picking, like laundering, is related to the concept of unspecified power, but it works slightly differently. ${ }^{25}$ Whereas laundering occurs when the specified power has a higher emission rate than the default rate, cherry picking occurs when the specified power has a lower emissions rate than the default rate. ${ }^{26}$ Again, this practice has been described as an act of active deception wherein electricity importers characterize actually unspecified, system-produced electricity as originating at a low-emitting source. ${ }^{27}$ However, a Californian electricity importer can achieve this same result by replacing its contracts for unspecified power with sources of power that emit less than the default emissions rate. ${ }^{28}$

Facility swapping occurs when an electricity importer replaces a contract for power from a source with higher emissions for a contract for power

20. See James Bushnell, ET AL., Downstream Regulation of CO2 EmisSions in CALIFORNiA's ElECTRICITY SECTOR 6 (2013), available at http://ei.haas.berkeley.edu/ pdf/working papers/WP236.pdf [hereinafter Bushnell, Downstream Regulation].

21. DAVID FARNSWORTH AND RACHAEL TERADA, TRACKING EMISSIONS ASSOCIATED with ENERgy SERVing LoAd in the Regional Greenhouse Gas Initiative States: A FEASIBILITY STUDY, APp. 3, at 57 (2013) [hereinafter Farnsworth, et al.].

22. CAL. Code Regs. tit. 17, § 95111(b)(1) (2013); Bushnell, Downstream Regulation, supra note 20 , at 6 .

23. Id.

24. Id.

25. Farnsworth, et al., supra note 21, at 57.

26. Id.

27. Id.

28. For a mathematical description of this more benign form of cherry picking, see Letter from Judi K. Mosley, Pacific Gas \& Electric, to Steven Cliff, Chief, Climate Change Markets Branch, California Air Resources Board (May 11, 2012), available at http://www. arb.ca.gov/lists/5-4-electricity-ws/9-051112_pg_e_comments_on_compliance_requirements_ 00125651-2_.pdf [hereinafter Letter from $\mathrm{PG} \& \overline{\mathrm{E}}]$. 
from a source with lower emissions. ${ }^{29}$ Nominally, this seems like ideal compliance with the objective of the state's cap-and-trade scheme: electricity importers replacing dirty sources of electricity with cleaner ones. However, because both clean and dirty sources in this scenario are outside of California, there is no absolute prohibition or limitation on the operation of the dirtier generating facility. Instead, the dirty electricity may simply be redeployed to serve another location's demand, resulting in no net reduction in emissions. Furthermore, because of the nature of the electricity market (electrons travel in the path of least resistance, according to the laws of physics), "green" electrons cannot be separated from "brown" ones. To whatever extent a California transaction leads to emissions reductions, they may only exist on paper. The hypothetical illustration above involving Plant A and Plant B appears to be an example of facility swapping.

Regardless of whether it is laundering, cherry picking or facility swapping, for California, the practical impact of shuffling poses a substantial threat to the ability of AB 32 to meet its goals. California imports 30 percent of the electricity consumed within its borders. ${ }^{30}$ Coal plants represent the most significant source of power imports, and GHG emissions from imported power account for as much as 47 percent of California's total emissions from the electricity sector. ${ }^{31}$ According to one analysis, resource shuffling "could result in leakage that exceeds the cumulative mitigation required under the cap-and-trade market through 2020."32 One study estimates the carbon dioxide leakage associated with resource shuffling at 108-187 million metric tons of carbon dioxide leakage, which translates to 47-197 percent of cumulative expected mitigation by 2020 under $\mathrm{AB} 32 .{ }^{33}$ Furthermore, California's fears of

29. See Danny Cullenward and David Weiskopf, Resource Shuffling And THE CALIFORNIA CARBON MARKET 10 (2013), available at http://www.law.stanford.edu/sites/ default/files/publication/440262/doc/slspublic/Resource\%20Shuffling\%20-\%20Cullenward $\% 20$ and \%20Weiskopf.pdf [hereinafter Cullenward \& Weiskopf].

30. California Energy Commission, California Electricity Statistics \& Data, THE CALIFORNia ENERGY ALmANAC, available at http://energyalmanac.ca.gov/electricity/ (last visited Mar. 4, 2014).

31. Cullenward \& Weiskopf, supra note 29, at 6.

32. See Danny Cullenward, Don't Let Accounting Tricks Dominate the Carbon Market, BERC ENERGY WEEK 2013, http://berc.berkeley.edu/digital-symposium/dont-letaccounting-tricks-dominate-the-carbon-market/ (last visited Mar. 6, 2014) [hereinafter Cullenward, Accounting Tricks].

33. Cullenward \& Weiskopf, supra note 29, at 2. 
resource shuffling are not entirely abstract. Californian independent electricity generators are particularly worried about the potential for laundering, especially in light of the Arizona Public Service Company's (APS) communications to the market that purchases of electricity from any of its generation assets should be treated as unspecified purchases from the Arizona system. ${ }^{34}$ If the market follows the APS's suggestion, then significant laundering could result because 61.7 percent of the APS's generation mix comes from sources that likely emit more than the default emissions rate. ${ }^{35}$

In the initial design of its cap-and-trade program, ARB addressed this potential gaming of the system by instituting an outright prohibition on resource shuffling. ${ }^{36}$ ARB originally defined resource shuffling as "any plan, scheme, or artifice to receive credit based on emissions reductions that have not occurred, involving the delivery of electricity to the California grid." ${ }^{37}$ In addition to its prohibition on shuffling, ARB planned on enforcing its anti-resource-shuffling regulations by imposing an attestation requirement on first deliverers. Under this attestation requirement, first deliverers would have to certify that they have not engaged in resource shuffling under penalty of perjury. ${ }^{38}$

\section{FERC'S RESPONSE AND CALIFORNIA'S NEW REGULATORY REGIME FOR RESOURCE SHUFFLING}

California's initial approach to banning resource shuffling at its borders presented a conflict with federal regulation of wholesale electric power markets in the western U.S., given the impact a blanket prohibition on shuffling at California's border could have on the operation of regional wholesale power markets. At the extreme, California's "attestation" antiresource-shuffling regulations potentially conflict with least-cost dispatch practices, which generally would lead transmission operators to favor the lowest cost sources of electric power in the interstate market. In addition, by

34. Letter from Jan Smutny-Jones, Exec. Dir., Indep. Energy Producers Ass'n, to Mary Nichols, Chair, Cal. Air Res. Bd. (July 10, 2013), http://www.arb.ca.gov/cc/reporting/ ghg-rep/revision-2013/iepattch.pdf [hereinafter Smutny-Jones].

35. Ariz. Pub. Serv. Co., 2012 Integrated Resource Plan 6 (2012, available at http://www.aps.com/library/resource\%20alt/2012ResourcePlan.pdf. 38 percent of the APS's mix comes from coal fire power plants, and 23.7 percent comes from natural gas. Id. The default emissions rate set by ARB is equivalent to a relatively clean-burning natural gas plant. Bushnell, Downstream Regulation, supra note 20, at 6 . Thus, even if all of the ASP's natural gas plants are clean burning, that still means that almost 40 percent of the ASP's generation assets probably exceed the default emission rate.

36. CAL. Code Regs. tit. 17, § 95852(b)(2) (2013).

37. CAL. Code Regs. tit. 17, § 95802(a)(252) (2013).

38. CAL. Code Regs. tit. 17, § 95852(b)(2)(A) (2013). 
influencing whose power may be purchased, California's anti-resource shuffling regulations can potentially affect grid reliability. Following federal regulators' request that California suspend its shuffling attestation requirement and prohibition, California has developed a new approach to regulating shuffling. Rather than prohibit all shuffling at its border without defining which practices are and are not shuffling, the new California resource shuffling regulations focus on identifying which practices are not shuffling, so that power producers and importers hopefully will have clarity regarding transactions to serve power demand in California.

\section{A. FERC's Response and the Impact on Wholesale Power Markets}

On May 4, 2012, ARB held a meeting with stakeholders to discuss its first deliverer approach and its resource-shuffling regulations. ${ }^{39}$ In response, twenty-two participants filed comments with CARB, the bulk of which protested the vagueness of the ARB definition for resource shuffling. ${ }^{40}$ Many of these participants commented that ARB's definition of resource shuffling could cover transactions that are standard or even legally mandated in the electricity market. ${ }^{41}$ These commentators wanted ARB to develop a more detailed definition of resource shuffling that would specify when an electricity transaction would and would not qualify as resource shuffling. ${ }^{42}$ Some also wanted ARB to develop procedures for ex ante, case-by-case guidance similar to no-action letters. ${ }^{43}$ Some even submitted competing comments on the problems that could arise as a result of ARB depending on NERC's e-Tags for its definition of electricity

39. See CAL. Air Res. BD., CAP-AND-TRAde Program Electricity (2012), available at http://www.arb.ca.gov/cc/capandtrade/meetings/050412/may4electricityppt.pdf.

40. These comments have been posted online. See Workshop Comments Log, CAL. Envtl. Protection Agency, Air Res. BD., http://www.arb.ca.gov/lispub/comm2/ bccommlog.php?listname=5-4-electricity-ws (last visited Sept. 13, 2013).

41. See Letter from Claudia Orlando et al., San Diego Gas \& Electric, to California Air Resources Board (May 11, 2012), http://www.arb.ca.gov/lists/5-4-electricity-ws/8sdge_commts-resource_shuffling_carb.5.11.12.docx [hereinafter Letter from SDG\&E]; see also Letter from PG\&E, supra note 28.

42. See, e.g., Letter from SDG\&E, supra note 41, at 1-3.

43. See, e.g., Comments of Sempra US Gas and Power on the California Air Resource Board 5/4/2012 Electricity Sector Workshop (May 4, 2012), http://www.arb.ca.gov/lists/ 5-4-electricity-ws/5-carb_5-4-2012_electricity_sector_workshop_-_sempra_usgp_comments. docx. 
importer. ${ }^{44}$ In any case, the consensus of the comments was that industry was concerned about the risk of excessive liability because of the combination of the perceived vagueness of resource shuffling and ARB's perjury-enforced attestation requirement. ${ }^{45}$

In addition to its vagueness, California's anti-resource-shuffling regulations may clash with least-cost-dispatch rules and practices. In wholesale power markets, power engineers and transmission operators routinely follow least-cost-dispatch practices, which would draw on the lowest cost marginal generation resource to meet expected power demand. ${ }^{46}$ However, under the anti-resource-shuffling regulations, factors other than low generation and bilateral procurement costs drive procurement decisions. These conflicting requirements can create confusion and uncertainty for market actors.

For example, Pacific Gas \& Electric's (PG\&E) comments in response to the May 4 meeting provide a simple, concise illustration of the kind of decision an electricity importer may face. ${ }^{47}$ PG\&E's primary concern was that the cost of allowances would increase the cost of higher-emission electricity to a point at which the otherwise more expensive purchase of lower-emission electricity would be mandated by their least-cost-dispatch practices ${ }^{48}$ However, by choosing the lower-emission electricity, and thus purchasing fewer allowances, PG\&E might run afoul of the anti-resourceshuffling rules because it would be taking credit for emissions reductions that do not necessarily occur. ${ }^{49}$ The selling utility could simply redeploy the higher-emission electricity to serve local or other non-Californian

44. Compare Letter from Mary Wiencke, PacifiCorp, to California Air Resources Board, at 1-7 (May 11, 2012), http://www.arb.ca.gov/lists/5-4-electricity-ws/11-arb_may 4 workshop comments pacificorp 051112.pdf, and Comments of J. Aron \& Company, at $\overline{1}-\overline{3}$ (May 11, 2012), http://www.arb.ca.gov/lists/5-4-electricity-ws/17-j_aron_capandtrade_ comment may4 2012 workshop.pdf (requesting that ARB not assert jurisdiction over out-of-state sellers selling power into the CAISO market), with Comments of Southern California Edison Company to the California Air Resources Board on the Public Meeting to Discuss Compliance Requirements for First Deliveries of Electricity, Held May 4, 2012, at 2, 8-9 (May 11, 2012), http://www.arb.ca.gov/lists/5-4-electricity-ws/13-2012-

05-11_sce_comments_on_electricity_imports_workshop.pdf [hereinafter Comments of Southern California $\bar{E}$ dison] (advocating for ARB to "[w]ork with the California Independent System Operator ("CAISO") to amend the CAISO Tariff in order to assert jurisdiction over out-of-state sellers who participate in the CAISO market, at nodes that are physically located outside California").

45. See, e.g., Comments of Southern California Edison, supra note 44, at 1-4, 6-7.

46. See CAL. Pub. Util. COMM’n, Dec. 02-10-062, Order InStituting RulEMAKInG to Establish Policies and Cost ReCOVERy MEChanisms fOR RUlEMaKing Generation Procurement And Renewable Resource DeVelopment, (2002), available at http://docs. cpuc.ca.gov/word_pdf/FINAL_DECISION/20249.pdf.

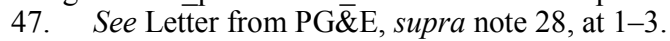

48. Id.

49. Id. 
demand, in which case no emissions reductions would actually occur. While the particular example discussed in PG\&E's comments represents a possible case of cherry picking, ${ }^{50}$ one could easily imagine this same scenario playing out in the laundering or facility-swapping contexts.

This conflict strikes at the heart of California's cap-and-trade scheme. On the one hand, the purpose of cap-and-trade schemes is to force firms to internalize the pollution-related costs of their behaviors in order to promote societal welfare. Thus, cap-and-trade proponents should rejoice at a hypothetical electricity importer's decision to purchase lower-emission electricity based on the fact that the lower-emission electricity is cheaper. On the other hand, cap-and-trade proponents would undoubtedly be concerned that this transaction does not reduce total GHG emissions. Moreover, labeling such a transaction as resource shuffling could reduce the effectiveness of the cap-and-trade scheme by undermining the price competitiveness of low-emission electricity; if an electricity importer cannot claim credit for the purchase of low-emission electricity, then it will be unable to reduce its expenditure on allowances, even though it has purchased lower-emission electricity.

Another concern is that a prohibition of shuffling at California's border could exacerbate the industrial-relocation form of carbon leakage. Any prohibition of shuffling at California's border will almost certainly increase the price of power being imported into California relative to the price of power consumed elsewhere. Inevitably, this increase in the price of power imports will benefit Californian in-state energy producers. To the degree that the increase in the price of imported electricity protects in-state producers by subjecting both domestic and foreign producers to the cap-and-trade requirements, this consequence is not only intended but is the very goal of California's first-deliverer approach to carbon leakage. Because electricity producers will not be able to meet California's demand at lower cost by moving production outside of the regulated jurisdiction, the first-deliverer approach - as supported by the resource-shuffling prohibition -will prevent industrial-relocation carbon leakage in the electricitygeneration sector. However, by increasing the price of all electricity consumed in California, this regulatory scheme may push mobile electricity-

50. This example would be cherry picking because PG\&E would be choosing between unspecified power, with its associated default emissions rate of .428 MT/MWh, and a specified zero-emission power source. Letter from PG\&E, supra note 28. See Farnsworth, supra note 25, at 57. 
intensive consumers - for example, factories - out of California, where they can purchase more and dirtier electricity.

Beyond potentially shifting electricity demand out of California, a resource shuffling prohibition at California's border can affect the reliability of the grid elsewhere in the Western United States. To the extent that California prohibits its utilities from shuffling dirty power supply contracts with cleaner ones, this has impacts on the power resource mix elsewhere and on the transmission grid. Different types of power generation require different amounts of transmission capacity in order to address variability in the resource's output. Power produced by wind, for example, requires significantly more transmission capacity than coal fired power. ${ }^{51}$ This is because coal and natural-gas power plants have historically been constructed close to the demand that they serve - and thus require relatively little transmission-whereas renewable energy technologies like wind and solar, for example, can produce electricity most efficiently only in locations that have the most wind and sunshine. ${ }^{52}$ Put simply, making power dispatch decisions outside of California based on Californian emission limitations will influence the resource mix and the transmission capacity necessary to meet this mix. Given that not every power plant is located an equal distance from California, there is also a possibility that some resources will require additional transmission simply to make up for the physical line loss associated with transmitted electric power over geographic distance.

Perhaps having heard some of the complaints raised in response to the May 4 meeting, FERC Commissioner Moeller wrote to California Governor Brown requesting that $\mathrm{ARB}$ suspend its enforcement of the anti-resourceshuffling regulations. ${ }^{53}$ This letter echoed the worries of the electricity industry over the vague definition of resource shuffling and the affirmation requirement. ${ }^{54}$ In particular, FERC expressed its concern that this vagueness combined with the threat of a perjury prosecution might create a chilling effect on the Californian electricity market. ${ }^{55}$ FERC was also likely concerned that California's prohibition on shuffling could effectively allow the state to regulate power plants outside of its borders. FERC has jurisdiction over "the transmission of electric energy in interstate

51. See Matthew L. Wald, Giving the Grid Some Backbone, SCIENTIFIC AMERICAN (Mar. 1 2009), http://www.scientificamerican.com/article/giving-the-power-grid-somebackbone/.

52. Id.

53. Letter from Moeller, supra note 8.

54. Id.

55. Id. 
commerce" and "the sale of electric energy at wholesale in interstate commerce." $" 56$

\section{B. California's New "Safe Harbors" for Resource Shuffling}

Commissioner Moeller's letter proved sufficient for ARB to suspend enforcement of some of its anti-resource-shuffling regulations. ${ }^{57}$ Ten days after the commissioner sent this letter, ARB Chairman Mary D. Nichols wrote back to FERC to inform the agency that ARB had decided to suspend the attestation requirement for the first eighteen months of active allowance trading. ${ }^{58}$ On September 20, 2012, ARB formally suspended enforcement of the attestation requirement. ${ }^{59}$ Covered entities will no longer need to attest that they have not engaged in resource shuffling under the threat of perjury.

On October 18, 2012, ARB formally resolved to refine the definition of resource shuffling. ${ }^{60}$ In this resolution, ARB proposed thirteen safe harbors, transactions in the electricity market that would be per se excluded from the definition of resource shuffling. ${ }^{61}$ These proposed safe harbors survived largely untouched in ARB's draft regulation, which was published in July 2013. ${ }^{62}$

The Draft Regulation eliminates the attestation requirement altogether. ${ }^{63}$ Covered entities will no longer need to attest that they have not engaged in resource shuffling under the threat of perjury. In addition, the Draft Regulation amends the definition of resource shuffling to read: "[A]ny plan, scheme, or artifice undertaken by a First Deliverer of Electricity to substitute electricity deliveries from sources with relatively lower emissions for electricity deliveries from sources with relatively higher emissions

56. 16 U.S.C. $\S 824(b)(1)(2012)$.

57. Letter from Nichols, supra note 8 .

58. Id.

59. Resolution 12-33, supra note 8.

60. Resolution 12-51, supra note 8.

61. CAL. Air Res. BD, Attachment $A$ to Resolution 12-51 (2012), available at http://www.arb.ca.gov/cc/capandtrade/attachmenta.pdf [hereinafter ARB, Attachment A to Resolution 12-51].

62. Compare id., with Cal. Air Res. Bd, Article 5: California Cap on Greenhouse Gas Emissions and Market-Based Compliance Mechanisms § 95852(b)(2)(A), at 96 (2013), available at $\mathrm{http}: / / \mathrm{www}$. arb.ca.gov/cc/capandtrade/meetings/071813/ct_reg_2013_ discussion_draft.pdf [hereinafter Discussion Draft].

63. Discussion Draft, supra note 62, § 95852(b)(2), at 96. 
resources to reduce its emissions compliance obligation." ${ }^{64}$ This definition is more of a refinement than a revolution of the earlier definition. By focusing on the substitution of lower emission electricity for higher emission electricity, the new definition better captures the mechanisms of resource shuffling. Indeed, the one feature that laundering, cherry picking, and facility swapping have in common is that they all involve first-importer utilities moving from nominally higher emissions electricity sources to nominally lower emissions sources. ${ }^{65}$ In addition to modifying the definition of resource shuffling, the Draft Regulation has provided a specific example of the kind of activities that would constitute resource shuffling. ${ }^{66}$

The July 2013 Draft Regulation further changes the definition of resource shuffling by adopting the thirteen safe harbors that ARB originally proposed in October 2012. ${ }^{67}$ According to ARB staff, these include situations where utilities are required to deliver electricity, situations where lower emission electricity replaces higher emission electricity due to circumstances beyond a utility's control, situations where power from high emission sources is cut back due to low electricity demand, and short term transactions that occur for economic reasons - such as congestion-rather than emissions regulations. ${ }^{68}$

The safe harbor provisions in the new definition of resource shuffling provided in the July 2013 Draft Regulation have come under criticism for being too permissive and broad in addition to allowing electricity importers to engage in considerable resource shuffling. ${ }^{69}$ Furthermore, these safe harbors have been criticized for failing to add clarity to the resource shuffling regulations. ${ }^{70}$ Economists Danny Cullenward and David Weiskopf single out Draft Regulation $\S \S 95852(\mathrm{~b})(2)(\mathrm{A})(6)$ and (8) as being especially broad and permissive. ${ }^{71}$ They appear to have identified a problem with California's new approach: It allows power deliverers to call a broad range of practices something other than shuffling, even where the effect of these practices is to increase or avoid reducing carbon emissions.

64. Id. § 95802(a)(252), at 47.

65. See generally supra notes $27-36$ and accompanying text.

66. Discussion Draft, supra note 62, § 95852(b)(2)(B), at 99

67. Compare Discussion Draft, supra note 62, § 95852(b)(2)(A), at 86, with ARB, Attachment A to Resolution 12-51, supra note 61.

68. Cal. Air Res. Bd, Staff Report: Initial Statement of Reasons, Proposed

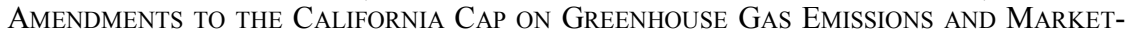
BASED COMPLIANCE MECHANISMS 30-31 (2013), available at http://www.arb.ca.gov/regact/ 2013/capandtrade13/capandtrade13isor.pdf [hereinafter ARB, Staff Report].

69. See Cullenward \& Weiskopf, supra note 29, at 19-27.

70. See id. at 31-33.

71. See id. at $21,23-24$. 
Under safe harbor 6, "electricity deliveries that substitute for deliveries that have been discontinued because of termination of a contract or divestiture of resources for reasons other than reducing GHG compliance obligation" is not resource shuffling. ${ }^{72}$ Cullenward and Weiskopf point out that "so long as [an electricity importer] could make a colorable argument that it was motivated by something other than the resource shuffling implications of its actions," it could theoretically shuffle resources without running afoul of the anti-resource-shuffling regulation. ${ }^{73}$ Interestingly, Cullenward and Weiskopf analyzed the language of the safe harbor provisions found in ARB's October 2012 resolution. ${ }^{74}$ The original sixth safe harbor contained the additional requirement that to avoid being counted as resource shuffling, new electricity deliveries must be "necessitated" by the termination or divestiture of dirtier resources. ${ }^{75}$ While Cullenward and Weiskopf are skeptical of the limiting force of the term necessitated, ${ }^{76}$ it is somewhat telling that even this potentially flimsy limit to accessing ARB's safe harbors has been removed.

Cullenward and Weiskopf are also especially critical of Draft Regulation $\S$ 95852(b)(2)(A)(8), which creates a safe harbor for "[e]lectricity deliveries that are necessitated by expiration of a contract." 77 Cullenward and Weiskopf argue that this safe harbor will incentivize participants in the California electricity market to enter into short-term contracts. ${ }^{78}$ Because these contracts will expire more frequently, Cullenward and Weiskopf argue, there will be more frequent opportunities for electricity importers to engage in resource shuffling with impunity. ${ }^{79}$ It is quite possible that Cullenward and Weiskopf overstate their case. Californian electricity importers will no doubt be familiar with the history of the California electricity crisis, in which California's prohibition on entering into longterm contracts left electricity purchasers vulnerable to the volatility and manipulation of the short-term electricity market. ${ }^{80}$ Wary of a repeat of

72. Discussion Draft, supra note 62, § 95852(b)(2)(A)(6), at 97.

73. Cullenward \& Weiskopf, supra note 29, at 23.

74. See id.; ARB, Attachment A to Resolution 12-51, supra note 61.

75. ARB, Attachment A to Resolution 12-51, supra note 61.

76. Cullenward \& Weiskopf, supra note 29, at 23.

77. Discussion Draft, supra note 62, § 95852(b)(2)(A)(8); see Cullenward \& Weiskopf, supra note 29, at 24.

78. Cullenward \& Weiskopf, supra note 29, at 24.

79. Id.

80. Fred Bosselman ET AL., ENERGy, ECONOMICS, AND THE ENVIRONMENT: CASES AND MATERIALS 710-11 (3d. ed. 2010). 
2000 and 2001, electricity importers likely will not abandon long-term contracts en masse merely to engage in shuffling.

Safe harbor 1 also presents problems for the emissions-reduction goal of the cap-and-trade program, but these problems are fewer than one might think. Under safe harbor 1, shuffling does not include any "[e]lectricity deliveries that are caused by the procurement of electricity eligible to be counted towards and purchased for Renewable Portfolio Standard (RPS) compliance in California." 81 Essentially, this means that first deliverers can engage in facility swapping or cherry picking so long as the lower-emission, specified power source in question comes from a renewable energy source and the generating facility meets certain tracking requirements. ${ }^{82}$ On one hand, this could lead to significant carbon leakage because shuffling is no less real merely because a renewable resource is involved.

On the other hand, after December 31,2016, 75 percent or more of the renewable electricity counted towards Californian utilities' RPS compliance requirements must come from sources whose contribution to the Californian electricity market cannot require a substitute power source elsewhere ${ }^{83}$ This means that only 25 percent of electricity procured pursuant to the RPS will be able to come from shuffled electricity contracts, which significantly limits the potential for the RPS safe harbor to undermine the prohibition on shuffling.

Nevertheless, Cullenward and Weiskopf correctly fault the safe harbors as overly broad and permissive. Many of the safe harbors have been drafted purposively, and are thus defined in terms of transactions "made for the purpose of" XYZ. ${ }^{84}$ Covered entities could easily make the claim that resource-shuffling transactions were made with any one of the safe harbors' purposes in mind. ${ }^{85}$ Moreover, depending on the burden of proof for establishing safe-harbor protection-which has not been specified in

81. Discussion Draft, supra note 62, § 95852(b)(2)(A)(1), at 96.

82. Cullenward \& Weiskopf, supra note 29, at 21; see CAL. ENERGY COMM'N, Renewable PoRTfolio Standard Eligibility 57-91 (7th ed. 2013), available at http:/www.energy.ca.gov/2013publications/CEC-300-2013-005/CEC-300-2013-005-ED7-SD -marked.pdf.

83. Cal. Pub. Util. Code $§ 399.16(b)(1)$, (c) (2013); Cal. Public Utilities COMM'N, DEC 11-12-052, ORDER INSTITUTING RULEMAKING TO CONTINUE IMPLEMENTATION and Administration of California Renewables Portfolio Standard Program (2011), available at http://docs.cpuc.ca.gov/WORD_PDF/FINAL_DECISION/156060. PDF. This nonsubstituted electricity must comprise no less than 50 percent of the utilities' RPS requirement in the compliance period ending on December 31,2013, and no less than 65 percent of the utilities' RPS requirement in the period ending on December 31, 2016. See CAL. Pub. Util. CODE $\S 399.16$ (b)(1), (c) (2013).

84. See, e.g., Draft Regulation, supra note 62, § 95852(b)(2)(A)(2), at 96 (exempting "electricity deliveries made for the purpose of compliance with state or federal laws and regulations" from the definition of resource shuffling) (emphasis added).

85. See. e.g., Cullenward \& Weiskopf, supra note 29, at 22. 
the regulation ${ }^{86}$ - ARB or any other enforcement body may have to prove the electricity importer's subjective intent. If, for example, ARB were to bring an enforcement action against an electricity importer and the electricity importer counters that it made the transaction in question for the purpose of complying with NERC Reliability Standards, ${ }^{87}$ then if ARB has the burden of proving that a safe harbor does not exist as part of its case in chief, the agency would have to prove that the electricity importer entered into the transaction for some purpose other than compliance with NERC Reliability Standards. If this were the case, the difficulty of bringing an enforcement action would likely undermine the effectiveness of the ban.

Furthermore, these safe harbors, despite their number and breadth, do not lend the regulatory regime sufficient clarity to mollify the original concerns about market confusion. The safe harbors are so broad that they undermine effective enforcement, and at the same time they are also too vague to provide reassurance to the industry. For example, these safe harbors do not satisfactorily answer PG\&E's questions: would the decision to switch from a higher-cost, higher-emission electricity source to a lowercost, lower-emission electricity source pursuant to least-cost dispatch requirements constitute shuffling? If so, how should PG\&E structure its procurement decisions?

With regard to the first question, safe harbor 2 creates significant uncertainty. ${ }^{88}$ Because the decision to switch to lower-emission electricity would be motivated by a desire to comply with least-cost dispatch requirements mandated by the California Public Utilities Commission (CPUC), ${ }^{89}$ this transaction would seem to qualify under safe harbor 2 . However, from a consequentialist perspective, ARB probably did not intend such a result, because that would mean that the prohibition on resource shuffling would never apply any time that lower-emission electricity, by virtue of its smaller allowance-purchase requirement, was cheaper than higher-emission electricity. This would exempt every instance of shuffling

86. See id. at 32, 39 (including an explicit burden of proof in the authors' proposed regulation).

87. See Discussion Draft, supra note $62 \S 95852(\mathrm{~b})(2)(\mathrm{A})(3)$, at 96-97.

88. See id. $\$ 95852(\mathrm{~b})(2)(\mathrm{A})(2)$ at 96.

89. See Cal. Pub. Util. Comm'n, Dec. 02-10-062, Order Instituting Rulemaking to Establish Policies and Cost Recovery Mechanisms, at 1-3 (2002), available at http://docs. cpuc.ca.gov/word_pdf/FINAL_DECISION/20249.pdf. PG\&E Letter, supra note 28, at 13 . 
from the prohibition - or at least enough instances of shuffling so as to nullify the prohibition - although theoretically, first deliverers would not be exempt from the prohibition if the lower-emission electricity cost more than the higher-emission electricity. But one would have to wonder when and why a first deliverer would switch to a source of electricity that cost more than its alternatives, and how an electricity importer could make such a decision without running counter to least-cost dispatch practices.

If, as is likely the case, PG\&E's hypothetical transaction were not allowed to qualify for safe harbor 2, then it remains unclear what PG\&E could or would be required to do. Most likely, PG\&E would not be able to reduce its compliance obligation by purchasing the lower-emission electricity. But this solution is not as simple as it seems. Expanding on the hypothetical offered in PG\&E's comments, one could imagine a highly efficient (low-emission) natural gas power plant whose bilateral contract price of electricity was less than that for an inefficient, dirtyburning coal-fire power plant - not an impossible hypothetical given recent prices of natural gas. One could even imagine the contract price of the natural-gas power plant's electricity being so low that purchasing electricity from the natural-gas power plant would be less expensive even if PG\&E were not allowed to purchase fewer allowances. The question would then be- how many allowances would PG\&E have to purchase? What would count as PG\&E's "original" source of electricity, for which it was substituting the lower-emission electricity from the natural-gas power plant? Given the number of sellers that a utility like PG\&E purchases from, there may be several options to choose from. Could PG\&E purchase allowances equivalent to the default emissions rate ${ }^{90}$ The regulations do not answer these questions satisfactorily.

\section{LOOKING UPSTREAM TO WHOLESALE POWER MARKETS FOR A SOLUTION TO SHUFFLING}

California's attestation and safe harbor approaches to regulating shuffling are seriously problematic, given the significant role that wholesale power markets play in supplying power to meet the demand of customers. California might attempt to address the leakage problems associated with shuffling on its own - perhaps by even setting a significantly higher implicit carbon price in its cap-and-trade system (by effectively lowering its cap) but in the end shuffling only highlights the significance of regional and national markets in electricity for many states in the U.S. today. Given this significance, the ultimate solutions to carbon leakage problems must be national, not subnational. The EPA, for example, could address carbon

90. PG\&E Letter, supra note 28, at 3 (offering slight variations on these questions). 
leakage issues by adopting national emissions standards or, at the extreme, adoption of a national or international carbon tax. ${ }^{91}$ However, to the extent federal carbon emissions standards constitute a "floor," allowing states or regional air boards to adopt more rigorous carbon emissions standards, leakage will continue to plague subnational efforts to regulate carbon emissions. Another avenue would be for federal energy regulators to adopt, or encourage state or regional entities to adopt, upstream guidelines to manage carbon leakage in energy dispatch decisions. This article examines how FERC might develop such guidelines and how these kinds of federal guidelines may be superior to allowing subnational regulators to manage shuffling on their own.

\section{A. An Unlikely California Solution}

California's attestation and shuffling approaches do not adequately address the problems associated with shuffling. There may be minor tweaks that can clarify some of the ambiguity and close the loopholes associated with safe harbors, but ultimately California regulators are likely to favor California-produced electricity over electricity that is imported from outof-state. Such an approach does not bode well for the efficient operation of interstate power markets in the West or in other areas of the country where subnational carbon emissions requirements present a risk of similar carbon leakage from electric power usage.

Another possible solution, which the economist James Bushnell and his coauthors have proposed, ${ }^{92}$ would be to simply recognize that carbon leakage and shuffling is an economic reality and to assume that it will occur. If this assumption is made, the economic solution would seem to be to adjust the price of carbon accordingly. In a cap-and-trade system, where the price is implicit, this can only be achieved by reducing the cap on carbon, which would result in a rise in allowance prices. If the estimates above are correct in suggesting that the leakage associated with shuffling could constitute as much as $47-197$ percent of cumulative expected

91. Unless carefully designed to include border tax adjustments, even a national carbon tax does not solve the carbon leakage problem. For example, airlines can simply refuel in jurisdictions without a tax. For discussions of these complexities see Gilbert E. Mercalf \& David Weisbach, The Design of a Carbon Tax, 33 HARV. ENVTL. L. ReV. 499 (2009).

92. See Bushnell, Downstream Regulation, supra note 20. 
mitigation by $2020,{ }^{93}$ a substantial reduction in California's cap would be required.

Such a reduction in allowed carbon emissions may be what is necessary in order for a state like California or any subnational regulatory body to address the leakage associated with shuffling. Serious concerns already abound regarding whether the carbon price is too low, and an increase of this nature would have a variety of secondary benefits in moving towards lower carbon sources of power supply. However, such a substantial decrease in the cap seems politically controversial and unlikely, especially in an environment where California's approach has already generated substantial industry and political backlash.

\section{B. EPA and Carbon Leakage from Subnational Regulation}

Another potential solution is to recognize that, at its core, shuffling is a byproduct of a jurisdictional mismatch with subnational approaches to regulating carbon emissions. It is well recognized that problems associated with carbon emissions transcend any individual jurisdiction's ability to address the issue. The scale of the problem has been recognized to be national or even international in scope. ${ }^{94}$

Given this, a carbon tax or cap-and-trade program at the national level could be devised to address shuffling. A single price for carbon emissions that has a legally preemptive effect on subnational carbon regulation efforts, whether they occur in California or elsewhere, would eliminate incentives for shuffling at the subnational level. However, such an approach has not had sufficient political support at the national level in the U.S. and its future adoption seems unlikely. It also may be undesirable to completely preempt subnational efforts to adopt more restrictive carbon regulations than the federal government, given the disproportionate impact that climate change may have on some states. ${ }^{95}$

Short of adopting a price for carbon, the EPA has taken significant action towards regulating the carbon emissions from both new and existing power plants. How these standards are implemented could make a

93. See supra notes $31-33$ and accompanying text.

94. For discussion of the implications of the global impacts of carbon emissions on preemption and the choice of federal or state regulation, see Robert L. Glicksman \& Richard E. Levy, A Collective Action Perspective on Ceiling Regulation by Federal Environmental Regulation: The Case of Global Climate Change, 102 Nw. U. L. REv. 579 (2008).

95. As the decision in Massachusetts v. EPA indicates, some places are more likely than others to experience adverse effects arising from global climate change. Massachusetts v. EPA, 127 S. Ct. 1438, 1442-43 (2007). States bordering the ocean, for example, are at greater risk of flooding than are places that lack coastlines. 
significant difference in the incentives for shuffling at the subnational level. However, even a national emissions standard adopted by the EPA would likely present economic and regulatory challenges for any effort to eliminate shuffling, leaving the EPA ill-equipped to solve the problem on its own.

The first challenge is economic. In their present and anticipated form, any national GHG emissions standards for power plants will establish a floor, not a ceiling. States like California, or regional bodies such as RGGI, still may adopt more restrictive limitations on the emissions of carbon. More restrictive carbon emissions requirements will create the kinds of jurisdictional differences in power production costs across states that make shuffling attractive in the first place. Absent preemption of state carbon limits, economic incentives for private actors to engage in practices such as shuffling will continue.

The EPA may attempt to police this by approving state approaches to implementing the CAA, but the second challenge it will face is regulatory. In part because of the Clean Air Act's reliance on states, and in part due to diffuse political opposition to national carbon emissions standards, the EPA has signaled that it intends to be flexible in recognizing state compliance with any national standards. This kind of approach will present challenges to federal regulators given differences across states in the stringency of emissions approaches. Under section 111(d) of the CAA, the EPA seems likely to give states "credit" towards their emissions for various renewable, clean energy, and energy efficiency policies. As one author has noted:

\begin{abstract}
[Since] the stricter state programs do not result in increased stringency of the national program, those state programs may not reduce emissions, but rather simply export them to other states. Emitters that comply with strict state programs will over-comply with the federal standards, and therefore will have allowances or credits that can be traded to out-of-state emitters. The buyers of these credits can then emit the same amount of GHGs that the state sought to eliminate. Because GHGs are global pollutants, the state policy would see no environmental benefit. 96
\end{abstract}

This kind of problem seems inevitable if the EPA embraces flexibility in its compliance approach to any carbon emissions limits. There may be solutions, if for example a stricter state opts out of 111(d) flexibility or

96. See Nathan Richardson, Playing Without Aces: Offsets and the Limits of Flexibility Under Clean Air Act Climate Policy, 42 EnVTL. L. 735, 774 (2012). 
only allows tradable emissions for any emissions reductions that are beyond what both federal and state regulations require. ${ }^{97}$ But still, differences in state regulatory approaches will inevitably contribute to the economic incentives for shuffling, and short of a legally preemptive national price on carbon, the EPA does not appear to have a clear regulatory tool for managing the problem.

\section{Managing Shuffling Upstream, in Wholesale Power Markets}

Another underexplored avenue for controlling shuffling is to look upstream - to the economic incentives created by interstate power markets. Under Part II of the Federal Power Act, these markets are exclusively controlled by FERC, not by any other regulator. ${ }^{98}$ Although competitive markets favor least-cost dispatch practices, FERC has a statutory obligation to ensure that the wholesale rates charged in these markets are not unjust, unreasonable and unduly discriminatory, ${ }^{99}$ and to ensure reliability. ${ }^{100}$ National guidelines that prohibit shuffling could be a valid exercise of FERC's regulatory authority.

To imagine what federal energy market guidelines prohibiting shuffling might look like, one need only consider existing federal regulatory initiatives that cover interstate power markets. FERC already regulates the rates and reliability conditions imposed by Regional Transmission Organizations (RTOs) and Independent Service Operators, including California's Independent Service Operator. ${ }^{101}$ A substantial new initiative by FERC is focusing on transmission planning, and requires transmission organizations to consider state public policy requirements. ${ }^{102}$ These requirements conceivably could include state emissions reduction goals that go beyond federal emissions requirements, such as California's capand-trade program for carbon emissions. As part of its approval of transmission operation plans, FERC could specify its own least-cost protocols for regional markets with state or regional carbon emissions requirement. These protocols could include harmonized safe harbors that

97. Id.

98. FERC has exclusive jurisdiction over the "transmission of electric energy in interstate commerce," the "sale of electric energy at wholesale in interstate commerce," and "all facilities for such transmission or sale of electric energy." Federal Power Act (FPA) $\S 201,16$ U.S.C. $\S 824$ (b) (2012).

99. Federal Power Act (FPA) $\S \S 205-06,16$ U.S.C. $\S \S 824(d)-(e)$.

100. Id. $\S 215,16$ U.S.C. $\S 824(\mathrm{o})$.

101. See Order No. 888, 75 F.E.R.C. 61,080 (1996); Order No. 889, 75 F.E.R.C.

61,078 (1996); Order No. 2000, 89 F.E.R.C. 61,285 (1999).

102. Order No. 1000, 145 F.E.R.C. 61,252 (2013). 
would apply in regional power markets regardless of the jurisdictional differences in emissions requirements.

An upstream approach to managing shuffling by federal energy regulators would avoid potential preemption conflicts, as occurred between California regulators and FERC. From a political economy perspective, such a harmonized approach could serve to safeguard against individual states protecting in-state producers and discouraging the purchase of power on the interstate power market through their approach to managing shuffling. At the same time, such an approach would set the stage for a national approach to carbon regulation that still leaves space for subnational carbon emission approaches. Even with national carbon regulation, such guidelines could be important before national standards will only be a floor, so such an approach would better position energy markets to accommodate effective carbon regulation than the current approach of leaving the management of shuffling to state regulators.

\section{CONCLUSION}

The potential for shuffling in wholesale power markets thwarts California's ability to meet its AB 32 GHG emission reduction goals, and may even lead to emissions increases. Yet, as California's efforts illustrate, resource shuffling is extremely difficult to regulate at the state level. Short of California aggressively reducing its emissions limits to reflect the leakage problem of shuffling, the state is incapable of solving the problem on its own.

As states follow California's lead in crafting their own approaches to regulating GHG emissions, national solutions will be necessary to address the problem of resource shuffling, given interstate markets in wholesale electric power. Undoubtedly EPA can play a role, but its flexible approach to state carbon regulation suggests it is likely to leave the management of shuffling largely to states. Moreover, without some ability to preempt states the EPA too is ill-equipped to address shuffling. This Article has argued that the superior solution to resource shuffling lies upstream, in the electric power markets managed by FERC. For subnational carbon emissions regulation to meet its goals, it must be recognized that shuffling is a problem created by pricing practices in upstream interstate power markets. The ultimate solution to this problem lies with the federal regulators who manage these markets, not with individual states. 